\title{
Patient satisfaction in pediatric outpatient settings from the parents' perspective - The Child ZAP: A psychometrically validated standardized questionnaire
}

Eva Maria Bitzer ${ }^{1,2}$, Stephanie Volkmer ${ }^{3}$, Marco Petrucci ${ }^{2}$, Nikolaus Weissenrieder ${ }^{4}$ and Marie-Luise Dierks ${ }^{3^{*}}$

\begin{abstract}
Background: Patient surveys constitute a valuable source of information in patient-focused health care. The objective of this study was to develop and validate a standardized, patient centered, quantitative instrument to assess parent satisfaction in ambulatory pediatric care to be used in quality management and benchmarking activities, the Child-ZAP.
\end{abstract}

Methods: A preliminary version of the survey (38 items) was conducted in $n=19$ pediatric practices. After psychometric testing a modified Child-ZAP was tested in a second survey ( $n=20$ new pediatric practices). Data from $\mathrm{n}=979$ patients were available for analysis.

Results: The final version of the Child-ZAP contains eight dimensions, three "Child-Scales" and five "Parent-Scales". Confirmatory factor analysis confirms the three hypothesized child dimensions as well as the five parent dimensions. The factorial structure is confirmed in subgroups of younger and older children.

Conclusions: With satisfactory to good results for validity and reliability testing, the final Child-ZAP is applicable in pediatric ambulatory care for children of all age groups.

Keywords: Quality assurance, Patient satisfaction, Pediatrics, Questionnaires, Parents

\section{Background}

The patient's experience in health care institutions should be considered and incorporated into every stage of the health care process [1]. Only the patients themselves can authentically report their perceptions of health care processes and outcomes. Patient input is a valuable source of information needed for a patient-oriented organization of health care. Since the patients' major concern is to receive treatment and care that satisfies their needs [2], health care provider are interested in improving the quality of their services, not least regarding market competition and accountability $[3,4]$. Current quality management and certification procedures throughout health care sectors

\footnotetext{
* Correspondence: dierks.marie-luise@mh-hannover.de

${ }^{3}$ Medizinische Hochschule Hannover, Institut für Epidemiologie,

Sozialmedizin und Gesundheitssystemforschung, Forschungsschwerpunkt

Patientenorientierung und Gesundheitsbildung, Carl-Neuberg-Str. 1,

Hannover 30625, Germany

Full list of author information is available at the end of the article
}

(ambulatory care physicians, hospitals, rehabilitation centres) require patient surveys on satisfaction and outcomes of care [5,6]. Data from such surveys are used for benchmarking purposes and are made publicly accessible [7].

The dimensions of patient satisfaction have been described recently [8]. However, the issue of shared decisions making has become increasingly important during the last years $[9,10]$. There are a number of tools which are suitable for the assessment of the patient's perspective [11]. In quality management, good results have been achieved using standardized written surveys describing and assessing patient satisfaction and health care settings $[7,9]$. In order to minimize social desirability patient satisfaction surveys should be administered outside the health care providers' office [12].

The German ZAP outpatient satisfaction questionnaire is a standardized instrument to assess process-related patient satisfaction in outpatient care, which was developed 
in 1999 and validated by questioning adults, treated in general and specialized medical practices [13]. The ZAP (German Acronym for "Zufriedenheit in der Arztpraxis") is distributed free of charge in collaboration with the German Association of Statutory Health Insurance Physicians. When it comes to pediatric care, publicly available psychometrically sound instruments addressing processes of care from the patients' perspective become short: we used a standardized questionnaire or parents assessment of pediatric hospital care [14]. The parent satisfaction questionnaire considers two perspectives: the parents' assessment of the child-physician interaction (proxy report) and the parents' assessment of their own interaction with the physician (self-report). However, we are not aware of a validated questionnaire to assess pediatric and adolescent primary care available in Germany. To date, instruments measuring the satisfaction of parents and/or children within pediatric and adolescent primary care only exist in English-speaking countries $[15,16]$.

\section{Methods \\ Survey development}

The goal of the present study was to adapt two existing questionnaires to a survey of parents whose children are seen in pediatric and adolescent primary care practices: the ZAP questionnaire and the questionnaire of parent satisfaction with hospital care [14]). The notion to adapt the instrument to a children and adolescent self-report was abandoned because in German pediatric and adolescent primary care practices more than $50 \%$ of the patients are younger than 5 years of age [17], and thus unable to complete a written survey $[18,19]$. Instead, we decided to evaluate parents' assessment of health care quality and satisfaction from their child's perspective (proxy report). However, although children and adolescents are the main recipients of care, physicians still need to address and involve the child's parents. Therefore, it seems necessary to obtain the assessment of satisfaction and involvement with pediatric care reported by the parents.

The parent survey was designed to assess aspects of both the child-physician and the parent-physician relationship. Byczkowski et al. (2010) found a large degree of corresponding assessments between adolescent patients and their parents regarding patient satisfaction. Further, we decided against the use of different versions for various age groups to ensure that the questionnaire can be widely used for parents of children of all ages in every day pediatric outpatient care [20].

The Child-ZAP was developed from the validated ZAP questionnaire for adults [13] which contains four scales (23 items), and from a questionnaire of parent satisfaction with hospital care [14]. A preliminary qualitative study was conducted to assess the comprehensibility and relevance of questions of the adult version of the ZAP. This was done by conducting guided interviews with parents whose children were currently seen in pediatric and adolescent primary care practices as well as with older children and adolescents. Based on the results of the preliminary study and theoretical considerations, the adult version of the ZAP was modified into a preliminary version for children (Child ZAP).

The preliminary version of the Child ZAP contained six scales (24 items) for parent assessment of parentphysician interaction (self-report), three scales (14 items) for parent assessment of child-physician interaction (proxy report), and three global items (overall satisfaction with the physician, trust in the physician, and quality of care).

The preliminary version was then subjected to psychometric testing and modified accordingly into a second and final version of the Child ZAP, which then was tested in the main study with a random sample from selected pediatric and adolescent primary care practices. The results of the psychometric analysis, based on data gathered in the main study, are presented below.

The parents were instructed to answer the questions based on their overall satisfaction with the pediatrician in general, i.e., not merely based on the last doctor visit. This was included to ensure that the participants responded independent of their current doctor's appointment. All items were rated on a four-point scale ranging from "very satisfied" to "very unsatisfied". Two scales, the proxy report scales "Child - Information" and "Child Involvement" were coded with an additional response "Does not apply". The rationale behind this decision was the assumption that it would not always be possible or appropriate to provide information to very young children or involve them in decision making.

The questionnaire also contained supplementary questions on the current doctor visit and on sociodemographic characteristics of the parents and their children.

\section{Study design}

We decided to test the instrument in 20 practices in Northern Germany. In collaboration with the German Association of Pediatric and Adolescent Physicians (Berufsverband der Kinder- und Jugendärzte e.V.), all respective physicians in Lower Saxony, Bremen and Hamburg ( $n=750)$ were invited to take part in the study. Of 222 practices who responded positively, 20 practices were randomly selected.

No specific inclusion criteria were used for recruiting parents. However staff members were instructed to ensure that the participants were sufficiently fluent in German. Each practice received 100 questionnaires 
(including a letter and a stamped return envelope each), which were distributed randomly. The staff members instructed the parents to fill out the questionnaire at home and to return the questionnaire anonymously to the Hannover Medical School (MHH). The data collection for the preliminary study took place in winter 2007/ 2008, and for the main study in May 2009.

Participating doctors and patients were informed about the study. The Ethics Committee of the $\mathrm{MHH}$ approved the study (No 379, 2008).

\section{Data analysis}

To identify potential methodological weaknesses of the instrument and to reduce the number of items if possible, the preliminary study data collected in 19 pediatric practices were used to perform item and factor analyses considering wording quality criteria (item wordings related to quality management should be as specific and detailed as possible) and statistical criteria (including factor loadings of $<0.5$ for the respective factor and correlation of $<0.8$ with the respective subscale; item difficulty defined as the percentage of parents correctly answering the item.). The factorial structure of the preliminary version revealed high construct validity. However, considering the above mentioned criteria 5 items were removed from the questionnaire in order to reduce its length.

The optimized instrument consisted of three scales (14 items) for parent assessment of the child's interaction, information and involvement in decision making and five scales (19 items) for assessment of the parents' own experience (with practice organization, practice facilities, the provision of information, involvement in decision making, and professional competence).

The questionnaire items are shown in Table 1 (child scales) and Table 2 (parent scales).

The final psychometric analysis consisted of item analyses (e.g., discriminatory power, distribution and item difficulty) and tests of reliability and validity of the scales/subscales. Reliability was measured using a standardized coefficient of internal consistency (Cronbach's alpha). Construct validity was assessed by confirmatory factor analysis, which has been shown to be an adequate method for testing theoretically assumed factor structures of multidimensional scales [21,22]. Two confirmatory factor analyses were performed: the first analysis consisted of the 19 items which exclusively covered the assessment of the parents' own experiences; the second consisted of the 14 items for parent assessment regarding the relationship between child and physician. Included into the analyses were all cases with a valid response to all items needed for the respective confirmatory analysis. The Maximum Likelihood method was used to estimate the parameters, a procedure used if a sufficient sample size is available and the Bollen-Stine bootstrap is relatively insensitive to a violation of the normal distribution assumption $[22,23]$.

To determine whether the measurement model was appropriate for both younger and older children, the model previously defined for the overall sample was analysed in two parallel groups: children up to age 6 and children older than 6 years of age. Three models were compared with the unconstrained baseline model.

Table 1 Items on the "Child" scales

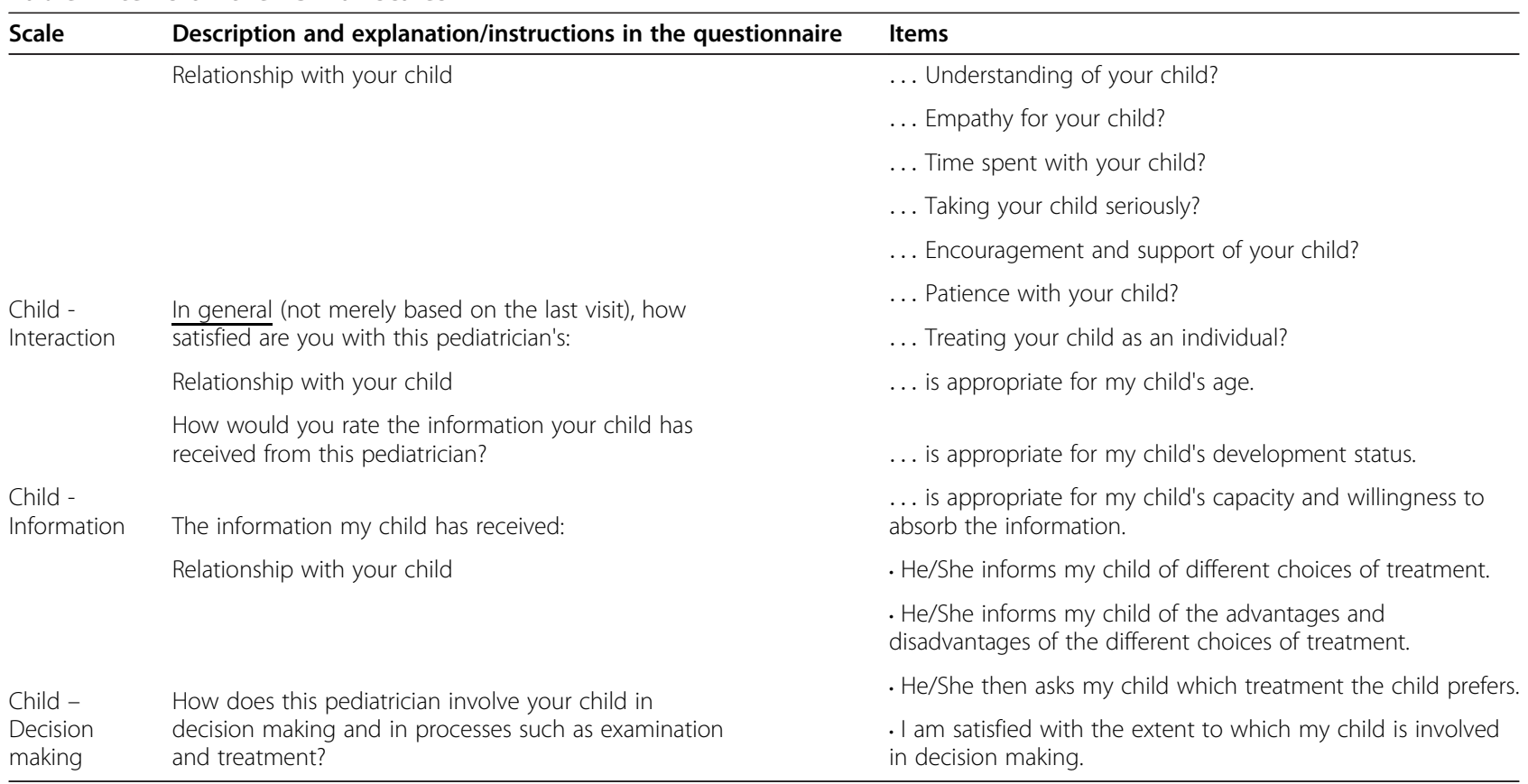


Table 2 Items on the "Parent" scales

\begin{tabular}{|c|c|c|}
\hline Scale & Description and explanation / instructions in the questionnaire & Items \\
\hline \multirow{4}{*}{$\begin{array}{l}\text { Practice } \\
\text { organization }\end{array}$} & \multirow[t]{4}{*}{ Satisfaction with practice organization and facilities } & ... Wait time for a doctor's appointment? \\
\hline & & ... Wait time in the waiting room? \\
\hline & & ... Consideration of your scheduling preferences? \\
\hline & & ... Friendliness of practice staff? \\
\hline \multirow{7}{*}{$\begin{array}{l}\text { Practice } \\
\text { facilities }\end{array}$} & \multirow{2}{*}{$\begin{array}{l}\text { In general (not merely based on the last visit), how } \\
\text { satisfied are you with: }\end{array}$} & ... Waiting room facilities? \\
\hline & & ... Play and entertainment facilities for your child? \\
\hline & \multirow[t]{5}{*}{ Relationship with you } & ... Information received about your child's illness? \\
\hline & & ... Information about planned treatments for your child? \\
\hline & & $\begin{array}{l}\ldots \text { Information on the effects of prescribed medications } \\
\text { for your child? }\end{array}$ \\
\hline & & $\begin{array}{l}\text {... Information on what you can do to promote } \\
\text { your child's recovery? }\end{array}$ \\
\hline & & ... Comprehensibility / clarity of information? \\
\hline \multirow[t]{4}{*}{$\begin{array}{l}\text { Parent - } \\
\text { Information }\end{array}$} & $\begin{array}{l}\text { In general (not merely based on the last visit), how } \\
\text { satisfied are you with this pediatrician in terms of: }\end{array}$ & $\begin{array}{l}\text {... consideration of side effects of prescribed } \\
\text { medications for your child? }\end{array}$ \\
\hline & \multirow[t]{3}{*}{ Relationship with you } & $\begin{array}{l}\text { - He/She informs me of different options (e.g., for } \\
\text { examination or treatment of my child). }\end{array}$ \\
\hline & & $\begin{array}{l}\text { - He/She informs me of advantages and disadvantages } \\
\text { of different options. }\end{array}$ \\
\hline & & . He/She asks me which option I prefer for my child. \\
\hline \multirow[t]{3}{*}{$\begin{array}{l}\text { Parent - } \\
\text { Decision making }\end{array}$} & $\begin{array}{l}\text { How does this pediatrician involve you in decisions } \\
\text { related to the examination and treatment of your child? }\end{array}$ & $\begin{array}{l}\text { - I am satisfied with the extent to which I am involved } \\
\text { in decision making. }\end{array}$ \\
\hline & \multirow[t]{5}{*}{ Relationship with you } & ... Collaboration with other medical facilities? \\
\hline & & ... Thoroughness and diligence in examinations? \\
\hline \multirow[t]{3}{*}{$\begin{array}{l}\text { Professional } \\
\text { competence }\end{array}$} & & $\begin{array}{l}\text {... Readiness to refer your child to another physician } \\
\text { in a timely manner? }\end{array}$ \\
\hline & & How well do you trust this pediatrician? \\
\hline & & $\begin{array}{l}\text { In general (not merely based on the last visit), how satisfied } \\
\text { are you with the quality of care by this pediatrician? }\end{array}$ \\
\hline Global items & $\begin{array}{l}\text { In general (not merely based on the last visit), how } \\
\text { satisfied are you with this pediatrician's: }\end{array}$ & $\begin{array}{l}\text { How satisfied are you with this pediatrician in general } \\
\text { (not merely based on the last visit)? }\end{array}$ \\
\hline
\end{tabular}

Model 1 referred to the assumption that there would be no statistically significant differences in any of the estimated parameters within the individual subsamples.

Model 2 was based on the assumption that the parameter estimates would differ only in terms of the error variance and that there would be no statistically significant differences between both subsamples in terms of the regression coefficients of the latent constructs for the observed individual items and of the inter-correlation of the latent constructs.

The third model implied that there would be no statistically significant differences in the regression coefficients of the latent constructs of the observed individual items in both subsamples.

Stability of the measurement model is not given unless the chi-square statistic of the model does not differ significantly from that of the unconstrained model [24].
The test of model quality was performed using the chi-square statistic, the comparative fit index (CFI), the Tucker-Lewis index (TLI), the Root Mean Square Error of Approximation (RMSEA), and the Standardized Root Mean Square Residual (SRMR). Model adaptation was determined to be acceptable based on the following criteria: non-statistically significant difference in chi-square statistic, high CFI ( $>0.95)$, high TLI ( $>0.95)$, low RMSEA $(<0.06)$, and low SRMR $(<0.11)$ [25-29].

An initial assessment of the convergent reliability was obtained by calculating correlations (Spearman correlation coefficient) between the subscales and the global items for satisfaction. We compared subscale means along different categories of wait times and consultation length by one way analysis of variance.

All statistical analyses were performed using SPSS for Windows V.17 and AMOS17 software. 


\section{Results}

\section{Sample characteristics}

A total of 979 valid questionnaires were available for analysis (range of responses by pediatric practice: $21 \%$ to $72 \%$; median: $50 \%)$. More than $90 \%$ of the questionnaires were completed by the mothers (see Table 3). The mean age of respondents was 35.4 years (SD: 6.6; range: 41), and the mean age of children treated in the pediatric and adolescent practices was 4.7 years (SD: 4.0; range: 16). The most frequent reasons for consultation were routine check-ups, vaccinations and acute disease symptoms.

\section{Item analyses}

Missing values ranged from $0.2 \%$ to $46 \%$ (Table 4; Table 5). All item difficulty values were above the theoretical scale midpoint; the mean values are 0.81 (child scales) and 0.79 (adult scales). The distributions of responses at item level were asymmetrical, with the majority of responses in the upper quarter of the response scales (Table 4; Table 5). The discriminatory power coefficients [30] were all significantly higher than $r=0.40$.

\section{Scoring and reliability of the subscales}

The items of each dimension were summarized into subscales. High subscale scores reflect a high degree of satisfaction. In addition, each subscale was transformed into scales ranging from 0 to 100 (Table 6; Table 7).

Table 3 Study population $(n=979)$

\begin{tabular}{|c|c|c|}
\hline Respondent & Mother & $94.3 \%$ \\
\hline & Father & $4.8 \%$ \\
\hline & other proxy (i.e. grandmother) & $0.3 \%$ \\
\hline Age of respondents & in years; $M(S D)$ & $35.4(6.6)$ \\
\hline Age of children & in years; $M(S D)$ & $4.7(4.0)$ \\
\hline \multirow[t]{4}{*}{$\begin{array}{l}\text { Age of children in } \\
\text { groups }\end{array}$} & Up to one year & $30,3 \%$ \\
\hline & $>1$ to up to 4 years & $28,6 \%$ \\
\hline & $>4$ to up to 7 years & $19,7 \%$ \\
\hline & $>7$ years & $21,4 \%$ \\
\hline $\begin{array}{l}\text { Knowing the } \\
\text { pediatrician }\end{array}$ & Years; M (SD) & $4.6(3.9)$ \\
\hline Wait time & in minutes; $M(S D)$ & $20.2(17.6)$ \\
\hline $\begin{array}{l}\text { Patient-pediatrician } \\
\text { contact time }\end{array}$ & in minutes; $M(S D)$ & $17.4(14.8)$ \\
\hline \multirow[t]{6}{*}{$\begin{array}{l}\text { Reasons for } \\
\text { appointment* }\end{array}$} & Routine check-up, vaccination & $36.2 \%$ \\
\hline & Acute disease symptoms & $44.1 \%$ \\
\hline & Chronic disease symptoms & $11.3 \%$ \\
\hline & Emergency & $1.3 \%$ \\
\hline & Prescription, attest, referrals & $13.9 \%$ \\
\hline & other & $5.7 \%$ \\
\hline
\end{tabular}

*Multiple answers possible $\mathrm{M}=$ Mean $\mathrm{SD}=$ Standard deviation.
All subscales showed that the distribution of responses was skewed to the left (subscale median values in the upper third, negative skewness and ceiling effects). This tendency was most pronounced in the subscales "Child Interaction" and "Child - Information". Ceiling effects were much less pronounced in all other scales. The internal consistency of the child-subscales was acceptable to good [31] with Cronbach's alpha ranging from 0.72 to 0.95 .

\section{Construct validity}

A confirmatory factor analysis of the dimensionality of the construct "patient satisfaction", as derived from the preliminary study data, was conducted using main study data (the parent and child scales of the Child ZAP were tested separately). The regression weights of the individual items of the respective scales on the latent factors, the squared multiple correlations of the individual item, and the correlations of the latent factors with each other are presented in (Additional file 1: Figure S1) and (Additional file 2: Figure S2). The parameters used to assess the quality of the overall model are specified.

Multiple criteria should be used for assessing the confirmatory factor analyses [21,22].

1. The individual parameter estimates should be plausible (i.e., the parameter estimates of the individual items should match theoretical considerations in terms of size and direction.

2. Negative variance estimates or correlations $>1$ should not occur.

3. Measurement errors should be within an acceptable range

Finally, different indicators of the overall quality of the model should be used.

As shown in the excerpts of the model estimates for the two models (Additional file 1: Figure S1) and (Additional file 2: Figure S2), all parameter estimates of the individual items exhibited positive correlations with the latent variables, and none of the parameter estimates was implausible. The correlations of the observed variables with the respective latent dimensions were high. The squared multiple correlations for the child scales ranged from 0.62 to 0.87 and were therefore within an acceptable range. The individual items of the parent scales were explained by the latent factors to a lesser degree; most of the squared multiple regression values ranged from 0.6 to 0.7 , but some values were lower.

As expected, the correlation between the latent factors was high, which implies that the individual dimensions of satisfaction with the pediatric and adolescent primary care physicians were not independent of each other. There were strong correlations between the three domains 
Table 4 "Child"-Scales- Item Statistics

\begin{tabular}{|c|c|c|c|c|c|c|c|}
\hline Variable & Subscale/Items & MV & $M$ & $S D$ & $\begin{array}{l}\text { Skew- } \\
\text { ness }\end{array}$ & $\begin{array}{l}\text { Item - } \\
\text { difficulty }\end{array}$ & $\begin{array}{l}\text { Item-total } \\
\text { corre-lation }\end{array}$ \\
\hline & Child - Interaction & $2.2 \%$ & 87.1 & 16.85 & -1.19 & & \\
\hline CHINT1 & Understanding & $0.2 \%$ & 2.7 & 0.54 & -1.34 & 0.89 & 0.84 \\
\hline CHINT2 & Empathy & $0.2 \%$ & 2.6 & 0.59 & -1.39 & 0.87 & 0.83 \\
\hline CHINT3 & Time spent with child & $0.2 \%$ & 2.5 & 0.69 & -1.16 & 0.83 & 0.78 \\
\hline CHINT4 & Taking child seriously & $1.5 \%$ & 2.6 & 0.55 & -1.3 & 0.88 & 0.84 \\
\hline CHINT5 & Ecouragement \& support & $0.9 \%$ & 2.5 & 0.61 & -1.11 & 0.85 & 0.83 \\
\hline CHINT6 & Patience & $0.4 \%$ & 2.6 & 0.55 & -1.23 & 0.88 & 0.81 \\
\hline \multirow[t]{2}{*}{ CHINT7 } & Treating child as an individual & $0.5 \%$ & 2.7 & 0.55 & -1.63 & 0.89 & 0.80 \\
\hline & Child - Information & $16.6 \%$ & 86.3 & 17.52 & -1.05 & & \\
\hline CHINFO1 & Age appropriate & $15.4 \%$ & 2.6 & 0.57 & -1.05 & 0.86 & 0.85 \\
\hline CHINFO2 & Appropriate to child's development stage & $15.4 \%$ & 2.6 & 0.55 & -1.02 & 0.87 & 0.87 \\
\hline \multirow[t]{2}{*}{ CHINFO3 } & Appropriate for child's capacity & $14.9 \%$ & 2.6 & 0.57 & -1.05 & 0.86 & 0.82 \\
\hline & Child - Decision-making & $46.2 \%$ & 66.3 & 29.63 & -0.60 & & \\
\hline ChDM1 & Offers choices about child's health care to child & $42.9 \%$ & 2.1 & 0.91 & -0.62 & 0.68 & 0.84 \\
\hline ChDM2 & $\begin{array}{l}\text { Discusses advantages and disadvantages of } \\
\text { different choices of treatment with the child }\end{array}$ & $46.2 \%$ & 2.0 & 1 & -0.54 & 0.65 & 0.88 \\
\hline ChDM3 & Asks child about preferred choice of treatment & $46.0 \%$ & 1.9 & 1 & -0.49 & 0.64 & 0.89 \\
\hline ChDM4 & $\begin{array}{l}\text { Appropriate involvement of the child in } \\
\text { decision-making }\end{array}$ & $45.8 \%$ & 2.0 & 0.94 & -0.67 & 0.67 & 0.84 \\
\hline
\end{tabular}

MV: Missing values M: Mean SD: Standard deviation.

information, involvement in decision making and professional competence covered in the child scales and the parent scales covered in the child scales, and further between parent scales for information, involvement in decision making and professional competence.

The indicators for assessing the quality of the overall models were acceptable to good for both the child scales and the adult scales of the Child ZAP. Initial variance can be largely attributed to the model (CFI 0.95; TLI 0.95). Conversely, the proportion of residual variance not explained by the model were low (RMSEA 0.6/046 and SRMR 0.038/0.049). Thus, the values were within the recommended range. The chi-square statistic of the two models was highly significant. However, considering the large sample size, this should not be overrated [22].

\section{Stability of the measurement model - older and younger children}

The results of the test of stability of the measurement model are shown in Table 8. All compared models (i.e., those for both the child scales and the parent scales) featured comparable quality indices in the different subsamples of older and younger children. Regarding the child scales, in both samples with older and younger children, the latent factors were comparable and not significantly different in terms of explaining the observed individual items (as shown by the non-significant p-value for the chi-square statistic as compared to Model 3 with the unrestricted baseline model). Regarding the parent scales, the model with assumed non-statistically significant regression weights also exhibited a slightly significant difference from the unrestricted baseline model. Therefore, the measurement model and the assumed theoretical structure of the child scales can be replicated in different subgroups. The same applies to the parent scales, however, to a slightly lower extent only.

\section{Correlation between subscales and global items}

All subscales featured a positive and statistically significant correlation with the three global items overall satisfaction with the pediatrician, quality of care, and trust in the physician (Table 9). The subscales "interaction", "information" and "professional competence" showed a satisfying correlation with the three global items (correlation coefficient range: 0.55 to 0.63 ), whereas the subscale "practice organization" correlated slightly lower with the global items (correlation coefficient range: 0.39 to 0.41 ).

\section{Correlation between subscales and wait time/physician contact time}

As shown in (Additional file 3: Figure S3), a wait time of more than 30 minutes was associated with significantly lower satisfaction (10 points less than average) for all investigated aspects. The highest decrease was observed for satisfaction with practice facilities and 
Table 5 "Parent"-Scales - Item Statistics

\begin{tabular}{|c|c|c|c|c|c|c|c|}
\hline & Subscale/Items & MV & $M$ & $S D$ & $\begin{array}{l}\text { Skew- } \\
\text { ness }\end{array}$ & $\begin{array}{l}\text { Item } \\
\text { Difficulty }\end{array}$ & $\begin{array}{l}\text { Item-Total- } \\
\text { Correlation }\end{array}$ \\
\hline & Parent - Information & $10.3 \%$ & 80.9 & 19.22 & -0.85 & & \\
\hline Parlnfo 1 & Child's illness & $2.2 \%$ & 2.5 & 0.63 & -1.08 & 0.84 & .77 \\
\hline Parlnfo2 & Planned treatments & $4.3 \%$ & 2.5 & 0.6 & -0.96 & 0.84 & .77 \\
\hline Parlnfo3 & Effect of medications & $3.4 \%$ & 2.3 & 0.74 & -0.84 & 0.78 & .81 \\
\hline Parlnfo4 & $\begin{array}{l}\text { What one can do to } \\
\text { promote child's health }\end{array}$ & $3.0 \%$ & 2.4 & 0.72 & -1.02 & 0.8 & .79 \\
\hline Parlnfo5 & Comprehensibility & $1.8 \%$ & 2.5 & 0.62 & -1.11 & 0.84 & .77 \\
\hline \multirow[t]{2}{*}{ Parlnfo6 } & Consideration of side effects & $6.6 \%$ & 2.2 & 0.81 & -0.65 & 0.72 & .75 \\
\hline & Parent - Decision-making & $6.5 \%$ & 70.3 & 28.40 & -0.71 & & \\
\hline ParDM1 & $\begin{array}{l}\text { Offers choices of treatment for } \\
\text { the child's health care to parent }\end{array}$ & $5.0 \%$ & 2.1 & 0.88 & -0.66 & 0.7 & 0.85 \\
\hline & $\begin{array}{l}\text { Discusses advantages and } \\
\text { disadvantages about different } \\
\text { choices of treatment with }\end{array}$ & & & & & & \\
\hline ParDM2 & the parents & $5.3 \%$ & 2.1 & 0.96 & -0.7 & 0.69 & 0.84 \\
\hline ParDM3 & $\begin{array}{l}\text { Asks for parents' preferred } \\
\text { choice of treatment }\end{array}$ & $5.0 \%$ & 2.0 & 0.97 & -0.66 & 0.68 & 0.88 \\
\hline \multirow[t]{2}{*}{ ParDM4 } & $\begin{array}{l}\text { Appropriate involvement of } \\
\text { parents in decision making }\end{array}$ & $5.1 \%$ & 2.2 & 0.91 & -0.91 & 0.73 & 0.84 \\
\hline & Professional competence & $29.2 \%$ & 86.4 & 17.83 & -1.34 & & \\
\hline ProfComp1 & $\begin{array}{l}\text { Collaboration with other } \\
\text { medical faculties }\end{array}$ & $25.7 \%$ & 2.5 & 0.62 & -1.07 & 0.84 & 0.71 \\
\hline ProfComp2 & $\begin{array}{l}\text { Thoroughness and diligence } \\
\text { in examinations }\end{array}$ & $2.8 \%$ & 2.6 & 0.62 & -1.43 & 0.87 & 0.66 \\
\hline \multirow[t]{2}{*}{ ProfComp3 } & Readiness to refer the child & $22.5 \%$ & 2.6 & 0.63 & -1.62 & 0.87 & 0.73 \\
\hline & Practice organization & $0.0 \%$ & 85.2 & 14.38 & -1.10 & & \\
\hline POrg1 & Wait time for doctor's appointment & $0.7 \%$ & 2.6 & 0.56 & -1.49 & 0.88 & 0.55 \\
\hline POrg2 & Wait time in waiting room & $0.5 \%$ & 2.1 & 0.78 & -0.59 & 0.7 & 0.45 \\
\hline POrg3 & $\begin{array}{l}\text { Consideration of scheduling } \\
\text { preferences }\end{array}$ & $0.4 \%$ & 2.7 & 0.51 & -1.58 & 0.9 & 0.56 \\
\hline \multirow[t]{2}{*}{ POrg4 } & Friendliness of staff & $0.4 \%$ & 2.7 & 0.49 & -1.93 & 0.92 & 0.43 \\
\hline & Practice facilities & $0.0 \%$ & 73.9 & 23.38 & -0.53 & & \\
\hline PFacil1 & Waiting room facilities & $0.3 \%$ & 2.2 & 0.75 & -0.63 & 0.74 & 0.78 \\
\hline PFacil2 & Play and entertainment facilities & $0.6 \%$ & 2.2 & 0.74 & -0.59 & 0.73 & 0.78 \\
\hline
\end{tabular}

MV: Missing values M: Mean SD: Standard deviation.

practice organization ( -17 and -13 points, respectively). A patient-physician contact shorter than 10 minutes was also associated with lower satisfaction (Additional file 4: Figure S4). Short contact times with the physician had the highest effect on satisfaction with "Child - Involvement in decision making" and "Parent - Information" (-12 and - 11 points, respectively) and the lowest effect on satisfaction with patient organization and practice facilities ( -7 and -8 points, respectively). All differences were statistically significant on a $5 \%$ level. Interestingly, a very short wait time (less than ten minutes) as well as very long physician contact time (more than fifteen minutes) were also associated with lower satisfaction. These findings are consistent with findings from the validation study of the original ZAP questionnaire.

\section{Discussion}

\section{Psychometric analyses}

The construct validity of the Child ZAP is supported by the confirmatory factor analyses which were plausible in content and offer adequate results according to statistical criteria. The child and parent scales of the Child ZAP give a good representation of the multidimensional and multi-perspective construct of patient satisfaction with process quality in pediatric and adolescent primary care practices. The inter-correlations of the subscales, which 
Table 6 "Child"-Scales - Scale statistics and reliability

\begin{tabular}{llll}
\hline & Interaction & Information & Decision making \\
\hline "Chld-Scales" & & & 4 \\
Number of items & 7 & 3 & 503 \\
Responders ( $n$ ) & 957 & 816 & 48.6 \\
Missing values (\%) & 2.2 & 16.6 & $0 / 12$ \\
Subscale minimum/maximum & $0 / 21$ & $0 / 9$ & 8.0 \\
Subscale mean, raw & 18.3 & 7.8 & $0 / 100$ \\
Subscales transformed (min/max) & $0 / 100$ & $0 / 100$ & 66.4 \\
Subscale mean, transformed & 87.1 & 86.3 & 3.0 \\
Floor effect (\%) & 0 & 0.1 & 12.8 \\
Ceiling effect (\%) & 47.8 & 45.7 & -34 \\
Skewness & -1.18 & -1.14 & $0.8(0.74-0.84)$ \\
Inter-item correlation (min/max) & $0.71(0.65-0.83)$ & $0.81(0.78-0.84)$ & 0.94 \\
Cronbach's alpha & 0.95 & 0.93 & \\
\hline
\end{tabular}

were sometimes rather high, could be interpreted as a sign of redundancy in the instrument, leading to considerations to shorten the instrument or the individual subscales further. However, due to content related reasons (to obtain a wide diversity of potential aspects for quality management) and statistical reasons, it was decided not to shorten the tool. Moreover, the ChildZAP was not reduced any further, because it is designed for quality assurance in outpatient pediatric practices. Thus, not only the scale scores, but also the results at single item level is of interest and important, for example, for the scale "professional competence", which consists of the items "collaboration with other medical faculties", "thoroughness and diligence in examinations" and "readiness to refer the child." For this reason and due to specific requirements in outpatient pediatric practice the child-ZAP is significantly longer than the original adult ZAP.

\section{Strengths and limitations}

Although the ceiling effects were pronounced and corresponded to the "high" patient satisfaction observed in other studies [32,33], they were lower than those obtained from the ZAP questionnaire for adults [34]. For example, in the validation study for the adult ZAP the subscales "practice organization" and "professional competence" received maximum scores from more than $40 \%$ of persons surveyed, whereas in this study these subscales received a maximum score of only $27.2 \%$ and $36.4 \%$, respectively. Nevertheless, the skewness of distribution and the pronounced ceiling effects limit an interpretation of the results.

Table 7 "Parent-Scales - Scale statistics and reliability

\begin{tabular}{|c|c|c|c|c|c|}
\hline & Information & $\begin{array}{l}\text { Decision } \\
\text { making }\end{array}$ & $\begin{array}{l}\text { Professional } \\
\text { competence }\end{array}$ & $\begin{array}{l}\text { Practice } \\
\text { organization }\end{array}$ & $\begin{array}{l}\text { Practice } \\
\text { facilites }\end{array}$ \\
\hline \multicolumn{6}{|l|}{ "Parent"-Scales } \\
\hline Number of items & 6 & 4 & 3 & 4 & 2 \\
\hline Responder (n) & 878 & 915 & 693 & 966 & 973 \\
\hline Missing values (\%) & 10.3 & 6.5 & 29.2 & 1.3 & 0.6 \\
\hline Subscale minimum/maximum & $0 / 18$ & $0 / 12$ & $0 / 9$ & $0 / 12$ & $0 / 6$ \\
\hline Subscale mean, raw & 14.6 & 8.4 & 7.8 & 10.2 & 4.4 \\
\hline Subscales transformed ( $\mathrm{min} / \mathrm{max})$ & $0 / 100$ & $0 / 100$ & $0 / 100$ & $0 / 100$ & $0 / 100$ \\
\hline Subscale mean, transformed & 80.9 & 70.3 & 86.4 & 85.2 & 73.9 \\
\hline Floor effect (\%) & 0.2 & 3.4 & 0.2 & 0.2 & 0.8 \\
\hline Ceiling effect (\%) & 28.7 & 29.0 & 36.4 & 27.2 & 34.1 \\
\hline Skewness & -.75 & -.66 & -.64 & -1.1 & -.53 \\
\hline Inter-item correlation (min/max) & $0.67(0.57-0.79)$ & $0.79(0.75-0.83$ & $0.63(0.50-0.69)$ & $0.39(0.27-0.50)$ & 0.78 \\
\hline Cronbach's alpha & 0.92 & 0.94 & 0.84 & 0.72 & 0.88 \\
\hline
\end{tabular}


Table 8 ZAP - Confirmatory factor analysis - Model fit in younger and older children

\begin{tabular}{|c|c|c|c|c|c|c|c|}
\hline \multicolumn{2}{|l|}{ Model } & Chi2 & Df & p-value & CFI & RMSEA & SRMR \\
\hline \multicolumn{8}{|c|}{ "Child"-Scales } \\
\hline Model 0 & Unconstrained basic model & 424 & 148 & $<0.000$ & 0.96 & 0.62 & 0.040 \\
\hline \multirow[t]{2}{*}{ Model 1} & Constrained regression weights, covariances, and error terms & 508 & 176 & $<0.000$ & 0.95 & 0.063 & 0.050 \\
\hline & Model 1 vs. Model 0 & 84 & 28 & $<0.000$ & & & \\
\hline \multirow[t]{2}{*}{ Model 2} & Constrained regression weights and covariances & 447 & 162 & $<0.000$ & 0.96 & 0.063 & 0.040 \\
\hline & Model 2 vs. Model 0 & 23 & 14 & 0.06 & & & \\
\hline \multirow[t]{2}{*}{ Model 3} & Constrained regression weights & 434 & 159 & $<0.000$ & 0.96 & 0.063 & 0.040 \\
\hline & Model 3 vs. Model 0 & 10 & 11 & 0.53 & & & \\
\hline \multicolumn{8}{|c|}{ "Parent"-Scales } \\
\hline Model 0 & Unconstrained basic model & 692 & 282 & $<0.000$ & 0.95 & 0.049 & 0.049 \\
\hline \multirow[t]{2}{*}{ Model 1} & Constrained regression weights, covariances, and error terms & 820 & 326 & $<0.000$ & 0.94 & 0.05 & 0.064 \\
\hline & Model 1 vs. Model 0 & 128 & 44 & $<0.000$ & & & \\
\hline \multirow[t]{2}{*}{ Model 2} & Constrained regression weights and covariances & 763 & 306 & $<0.000$ & 0.94 & 0.049 & 0.06 \\
\hline & Model 2 vs. Model 0 & 71 & 24 & & & & \\
\hline \multirow[t]{2}{*}{ Model 3} & Constrained regression weights & 720 & 296 & $<0.000$ & 0.95 & 0.048 & 0.051 \\
\hline & Model 3 vs. Model 0 & 28 & 14 & 0.014 & & & \\
\hline
\end{tabular}

Legend:

$\mathrm{Chi}^{2}=$ Chi-Square-Statistic Df $=$ Degrees of freedom $\mathrm{CFI}=$ Comparative Fit Index . RMSEA = Root-Mean-Square-Error of Approximation SRMS = Standardized-Root-Mean. Square-Residual.

Further, it has to be noted that the participating practices and parents were not randomly selected, and not representative of the population. Although we provided an instruction for this random distribution, it was not possible to control that this was done correctly. Thus, a selection bias can not be ruled out. It would be desirable to validate the questionnaire in a population-based sample.

The relatively high percentage of missing values for the parent scale "professional competence" appears to be problematic. However, the two items on the "professional competence" scale that resulted in the high number of missing responses concerned the parent's opinion of the pediatrician's collaboration with other medical facilities and the pediatrician's readiness to refer the child. Thus, it can be assumed that many parents who did not provide a valid answer to these items did not have any experience regarding the physician's readiness to refer the patient or collaborate with other facilities, and are not able to answer these questions. As the probability of parents having such an experience presumably increases with their child's age, missing responses for these questions are most likely for parents of younger children. Post-hoc analyses of our data showed, that this assumption is supported by the decrease of percentage of missing data with increasing age of the child (data not shown).

\section{Practical implications and future developments}

Basically it can be assumed that the pediatric and adolescent primary care physicians were motivated to

Table 9 Correlation of ZAP subscales with global items on satisfaction with pediatric care $(\mathrm{n}=394$, complete cases analyses)

\begin{tabular}{llll}
\hline ZAP Subscales & Trust in doctor & Treatment quality & Satisfaction with doctor \\
\hline Child-Interaction & 0.56 & 0.60 & 0.62 \\
Child-Information & 0.49 & 0.50 & 0.45 \\
Child-Decision making & 0.52 & 0.59 & 0.54 \\
Parent-Information & 0.65 & 0.68 & 0.66 \\
Parent- Decision making & 0.50 & 0.58 & 0.53 \\
Professional competence & 0.62 & 0.65 & 0.62 \\
Practice organization & 0.45 & 0.42 & 0.44 \\
Practice facilities & 0.32 & 0.37 & 0.37 \\
\hline
\end{tabular}

Legend: Spearman rank correlation, all correlations $p<0.0001$. 
participate in the study. The response rate of nearly $50 \%$ is comparable to similar patient surveys in German private practices. [12,35,36].

When assessing the process quality from the patient's point of view in pediatric and adolescent primary care rather than in adult health care, both the parents' as well as the child's perspective must be included. Therefore, the notion of "patient satisfaction in pediatric and adolescent primary care" is more complex than in adult primary care. This was taken into account while developing questions and scales which explicitly relate to the interaction between the physician and the child as well as to experiences and opinions of the accompanying parent.

The inclusion of the patient partnership in decision making as a component of health care process quality assessments, particularly patient satisfaction surveys, is a recent development $[10,11]$, and failure to do so is seen as a methodological deficiency [37,38]. Therefore, the Child ZAP questionnaire developers decided to include items and subscales to measure child and parent involvement in decision making even though it was known that this would lead to a high rate of missing data, particularly in cases where the patients were very young children. Considering that the Child ZAP is designed to apply to children of all ages, content-related considerations and the stability of the measurement models in both younger and older children support the decision to include the scale in the Child ZAP. However, it is recommended to restrict the analysis of this scale to children 5 to 6 years of age and older.

The fact that in a questionnaire used in outpatient pediatric practice, only the parents were interviewed, may at first seem strange. However, given the fact that more than half of the target population can not be interviewed directly due to their age, this decision appears to be justified. In addition, studies in which selfassessments of children and assessments by their parents are compared show a high correlation between these two measures [39-41].

\section{Conclusions}

The proposed instrument to assess patient satisfaction in pediatric and adolescent primary care practices shows psychometric qualities which justify its use in quality management. Due to specific circumstances in pediatric and adolescent primary care practice (child and adult interviewees), the Child ZAP is longer than the original adult version of the ZAP. Its modular design and feasible procedure allow for a flexible implementation of the survey instrument which meets various requirements of quality management. Considering the cultural diversity of patients seen in pediatric and adolescent medicine, a translation of the Child ZAP into other languages, such as Turkish, Serbian, Russian and English would be desirable.

\section{Additional files}

Additional file 1: Figure S1. Child ZAP: Confirmatory factor analysis of the "Child" scales (unrestricted baseline model).

Additional file 2: Figure S2. Child ZAP: Confirmatory factor analysis of the "Parent" scales (unrestricted baseline model).

Additional file 3: Figure S3. Child ZAP: Wait time at the practice.

Additional file 4: Figure S4 Child ZAP: Physician contact time.

\section{Abbreviations}

CFI: Comparative fit index; ChDM: Child-Subscale "Decision making"; Chi²: ChiSquare-Statistic; Child ZAP: Patient satisfaction in pediatric outpatient settings from the parents' perspective; CHINFO: Child-Subscale "Information; CHINT: Child-Subscale "Interaction"; Df: Degrees of freedom; M: Mean; MHH: Hannover Medical School; MV: Missing values; ParDM: Parent-Subscale "Parent-Decision making"; Parlnfo: Parent-Subscale "Parent-Information"; PFacil: Parent-Subscale "Practice facilities"; POrg: Parent-Subscale "Practice organization"; ProfComp: Parent-Subscale "Professional competence"; RMSEA: Root Mean Square Error of Approximation; SD: Standard deviation; SRMR: Standardized Root Mean Square Residual; TLI: Tucker-Lewis index; ZAP: Patient satisfaction with ambulatory care.

\section{Competing interests}

'The authors declare that they have no competing interests. NW is Member of the Board of German Association of Pediatric Physicians (BVKJ).

\section{Authors' contributions}

$E M B$ and MLD designed and oversaw the study, EMB and MP performed the statistical analysis, SV developed the questionnaire and organized the data collection, EMB, MLD and MP wrote the manuscript, NW recruited the participating physicians and critically revised the manuscript. All authors read and approved the final manuscript.

\section{Acknowledgements}

The Child ZAP was developed with financial and non-material support from the German Association of Pediatric Physicians (BVKJ).

We would like to thank all participating pediatric and adolescent primary care physicians for their support.

\section{Author details}

${ }^{1}$ ISEG-Institut für Sozialmedizin, Epidemiologie und Gesundheitssystemforschung, Lavesstr. 80, Hannover 30157, Germany. ${ }^{2}$ Pädagogische Hochschule Freiburg, Institut für Alltagskultur, Bewegung und Gesundheit, Gesundheitspädagogik, Kunzenweg 21, Freiburg79117, Germany. ${ }^{3}$ Medizinische Hochschule Hannover, Institut für Epidemiologie, Sozialmedizin und Gesundheitssystemforschung, Forschungsschwerpunkt Patientenorientierung und Gesundheitsbildung, Carl-Neuberg-Str. 1, Hannover 30625, Germany. ${ }^{4}$ Berufsverband der Kinder- und Jugendärzte e.V, Mielenforster Str. 2, Köln 51069, Germany.

Received: 27 February 2012 Accepted: 25 September 2012 Published: 2 October 2012

\section{References}

1. Gesundheitsministerkonferenz: Weiterentwicklung einer einheitlichen Qualitätsstrategie im Gesundheitswesen; 2006. http://www.gmkonline.de/ _beschluesse/Protokoll_79-GMK_Top92_Qualitaetsstrategie_Anlage2.pdf

2. Coulter A, Jenkinson C: European patients' view on the responsiveness of health systems and health providers. Eur J Public Health 2005, 15(Suppl 4):355-360.

3. Baker DW, Einstadter D, Thomas C, Husak S, Gordon NH, Cebul RD: The effect of publicly reporting hospital performance on market share and risk-adjusted mortality at high-mortality hospitals. Medical Care 2003, 41(6):729-740. 
4. Dierks ML, Seidel G, Schwartz FW, Horch K: Bürger- und Patientenorientierung in Deutschland. Gesundheitsbericht für Deutschland. Berlin: Robert Koch Institute; 2006

5. KTQ: KTQ-Leitfaden zur Patientenbefragung. Düsseldorf: Deutsche Krankenhausverlagsgesellschaft mbH; 2000.

6. Egner U, Gerwinn H, Schliehe F: Das bundesweite RehaQualitätssicherungsprogramm der gesetzlichen Rentenversicherung, Erfahrungen aus einem mehrjährigen Umsetzungsprozess. Zeitschrift für ärztliche Fortbildung und Qualität im Gesundheitswesen 2002, 96:4-9.

7. Dierks ML: Datenquellen und Methoden zur Erfassung der Versorgungsqualität aus Sicht der Nutzer - Behandlungszufriedenheit, Patientenerfahrungen und -bewertungen. In Monitoring der gesundheitlichen Versorgung in Deutschland - Konzepte, Anforderungen, Datenquellen. Edited by Kurth MB. Köln: Deutscher Ärzte-Verlag; 2008:197-210.

8. Sitzia J, Wood N: Patient satisfaction: a review of issues and concepts. Soc Sci Med 1997, 45:1829-1843.

9. Joosten EA, DeFuentes-Merillas $L$, de Weert GH, Sensky T, van der Staak CP de Jong CA: Systematic review of the effects of shared decision-making on patient satisfaction, treatment adherence and health status. Psychother Psychosom 2008, 77(Suppl 4):219-226.

10. Isfort J, Floer B, Butzlaff M: Shared Decision Making - Partizipative Entscheidungsfindung auf dem Weg in die Praxis. In Gesundheitsmonitor 2004. Die ambulante Versorgung aus Sicht von Bevölkerung und Ärzteschaft. Edited by Böcken B, Braun B, Schnee M. Gütersloh: Bertelsmann Stiftung; 2004:88-100.

11. Nübling $M$, Weber $H$, Zierath $M$, Langewitz W: Patient opinion surveys in the hospital: revalidation and improvement of a questionnaire. Psychother Psychosom Med Psychol 2003, 53(Suppl 5):236-242.

12. Dierks ML, Bitzer EM: Patientenbefragungen in der Arztpraxis Praktikabilität, Akzeptanz und Relevanz aus der Sicht von niedergelassenen Ärzten. Zeitschrift für ärztliche Fortbildung und Qualität im Gesundheitswesen 2000, 94(Suppl 8):389-395

13. Bitzer EM, Dierks ML, Dörning H, Schwartz FW: Zufriedenheit in der Arztpraxis aus Patientenperspektive. Psychometrische Prüfung eines standardisierten Erhebungsinstrumentes. J Public Health 1999, 7(Suppl 3):196-209.

14. GEK-Report akut-stationäre Versorgung 2008. In Schriftenreihe zur Gesundheitsanalyse. Edited by Bitzer EM, Grobe T, Neusser S, Dörning H, Schwartz FW. Schwerpunkt: Kinder im Krankenhaus; 2008:63.

15. Chesney $M$, Lindeke $L$, Johnson $L$, Jukkala A, Lynch S: Comparison of child and parent satisfaction ratings of ambulatory pediatric subspecialty care. J Pediatr Health Care 2005, 19(Suppl 4):221-229.

16. Simonian SJ, Tarnowski KJ, Park A, Bekeny P: Child, parent, and physician perceived satisfaction with pediatric outpatient visits. J Dev Behav Pediatr 1993, 14(Suppl 1):8-12

17. Grobe TG, Dörning H, Schwartz FW: GEK-Report ambulant ärztliche Versorgung 2008. St. Augustin: Asgard-Verlag; 2009.

18. Ravens-Sieberer U: Lebensqualitätsansätze in der Pädiatrie. In Lebensqualität und Gesundheitsökonomie in der Medizin: Konzepte, Methoden, Anwendung. Edited by Ravens-Sieberer U, Cieza A. Landsberg: Ecomed; 2000:277-292.

19. Seyfarth-Metzger I, Satzinger W, Höpner F, von Walter J: Kinder im Krankenhaus. Zur Methodik einer Kinder- und Elternbefragung. In Schriftenreihe Forum Sozial- und Gesundheitspolitik, Volume 15. Edited by Satzinger W, Trojan A, Kellermann-Mühlhoff P. St. Augustin: Asgard-Verlag; 2001:221-228.

20. Byczkowski TL, Kollar LM, Britto MT: Family experiences with outpatient care: do adolescents and parents have the same perceptions? J Adolesc Health 2010, 47(1):92-98.

21. Backhaus K, Erichson B, Plinke W, Weiber R: Der LISREL-Ansatz der Kausalanalyse. In Multivariate Analysemethoden. Edited by Backhaus K, Erichson B, Plinke W, Weiber R. Berlin, Heidelberg, New York: Springer; 1994:322-432.

22. Bühner M: Einführung in die Test- und Fragebogenkonstruktion. München: Pearson Studium; 2006

23. Garson GD: Structural Equation Modeling, Statnotes: Topics in Multivariate Analysis. http://faculty.chass.ncsu.edu/garson/pa765/statnote.htm

24. Arbuckle JL: AMOS 17.0 User's Guide. Chicago: Amos Development Cooperation; 2008
25. Hu LT, Bentler PM: Fit indices in covariance structure modeling: Sensitivity to underparameterized model misspecification. Psychol Methods 1998, 3(Suppl 4):424-453

26. Hu LT, Bentler PM: Cutoff criteria for fit indexes in covariance structure analysis: Conventional criteria versus new alternatives. Struct Equ Model 1999, 6(Suppl 1):1-5.

27. Bollen KA: Structural equations with latent variables. New York: Wiley; 1989.

28. Bentler PM: Comparative fit indices in structural models. Psychol Bull 1990, 107:238-246.

29. Browne MW, Cudeck R: Alternative ways of assessing model fit. In Testing structural equation models. Edited by Bollen KA, Long JS. Newbury Park, CA: Sage; 1993:136-162.

30. Bullinger M, Kirchberger I, Steinbüchel N: Der Fragebogen Alltagsleben ein Verfahren zur Erfassung der gesundheitsbezogenen Lebensqualität. Z Med Psychol 1993, 3:121-131.

31. Lienert GA: Testaufbau und Testanalyse. Verlag Julius Beltz: Weinheim; 1969

32. Raspe $H$, Weber U, Voigt $\mathrm{S}$, Kosinski A, Petras $\mathrm{H}$ : Qualitätssicherung durch Patientenbefragungen in der medizinischen Rehabilitation: Wahrnehmungen und Bewertungen von Rehastrukturen und -prozessen ("Rehabilitationszufriedenheit"). Rehabilitation 1997, 36:XXXI-XLII.

33. Aust B: Zufriedene Patienten? Eine kritische Diskussion von Zufriedenheitsuntersuchungen in der gesundheitlichen Versorgung. Berlin: WZB; 1994.

34. Dierks ML, Bitzer EM: Wie kann man Erwartungen und Zufriedenheit der Patienten im Qualitätsmanagement berücksichtigen? -

Erhebungsverfahren und Erfahrungen aus der ambulanten Versorgung. In Qualitätsmanagement in der Arztpraxis. Schriftenreihe des Bundesministeriums für Gesundheit, Band 117. Edited by Baden-Baden HB. Nomos Verlagsgesellschaft; 1999:125-184.

35. Klingenberg A, Bahrs O, Szecsenyi J: Was wünschen Patienten vom Hausarzt? Z Allgemeinmed 1996, 3(Suppl 72):180-186.

36. Jung HP, Wensing $M$, Grol R: What makes a good general practitioner: do patients and doctors have different views? Br J Gen Pract 1997 47:805-809.

37. Berger $B$, Lenz M, Mühlhauser I: Patient zufrieden, Arzt gut? Inwiefern ist Patientenzufriedenheit ein Indikator für die Qualität der hausärztlichen Versorgung? Eine systematische Übersichtsarbeit. Z Evid Fortbild Qual Gesundhwes 2008, 102(Suppl 5):299-306.

38. Härter M, Loh A, Spies C: Gemeinsam entscheiden - erfolgreich behandeln. Neue Wege für Ärzte und Patienten im Gesundheitswesen. Köln: Deutscher Ärzteverlag; 2005.

39. le Coq EM, Boeke AJ, Bezemer PD, Colland VT, van Eijk JT: Which source should we use to measure quality of life in children with asthma: the children themselves or their parents? Qual Life Res 2000, 9(6):625-636.

40. Erhart M, Ellert U, Kurth BM, Ravens-Sieberer U: Measuring adolescents'HRQoL via self reports and parent proxy reports: an evaluation of the psychometric properties of both versions of the KINDL-R instrument. Health Qual Life Outcomes 2009, 7:77.

41. Verhulst FC, Althaus M, Berden GF: The Child Assessment Schedule: parent-child agreement and validity measures. J Child Psychol Psychiatry 1987, 28(3):455-466

\section{doi:10.1186/1472-6963-12-347}

Cite this article as: Bitzer et al:: Patient satisfaction in pediatric outpatient settings from the parents' perspective - The Child ZAP: A psychometrically validated standardized questionnaire. BMC Health Services Research 2012 12:347. 